\title{
LEGAL REGULATION AND CERTIFICATION OF ORGANIC PRODUCTION IN UKRAINE
}

The article examines the current state and prospects of development of the national regulatory system in the sphere of organic agricultural production. It is shown that the existing state control system of organic production in Ukraine, built on the basis of the combined (public-private) European model, tends to be rather complicated and entangled, while the powers and responsibilities of the state authorities are too dispersed and the procedures of conversion to organic production and its certification are not clearly determined. It is grounded that the present regulatory and certification systems of organic production in Ukraine do not operate in a proper way because of a considerable delay of the necessary bylaws development and adoption; a notable lack of highly qualified and welltrained professionals in the field of organic standards, in particular among the public servants of the respective state authorities; indeterminacy of penal sanctions for violations of legislation related to organic production and marketing.

Keywords: organic production; organic certification; organic market; legal regulation.

Scientific problem. Popularization of healthy lifestyle and principles of sustainable environmental management in the world led to the increase of consumer concern over the healthiness of food and the way it is produced, as well as the effect of farming methods on the environment and animal welfare. The demand for organic products is constantly growing. More and more customers are willing to pay higher prices for agricultural and food production of a better quality and higher safety level. These global tendencies are true for Ukrainian domestic market too. According to Organic Federation of Ukraine the organic market capacity raised up to 17 million Euros in 2015 [5], while following the methodology developed by the researchers of the National Scientific Centre «Institute of Agrarian Economics» of UAAS, the potential capacity of the organic market in Ukraine, which can be reached by 2020, was estimated in around 40 billion UAH [4, p. 6].

Certification and legal regulation play a very important part in the process of organic food production and marketing development. On the one hand, these factors influence on organic products' consumers, ensuring that the labeled and certified products have better characteristics of quality and safety than traditional. On the other hand, legal regulatory and certification system is the one and the most effective way to protect the genuine organic producers from unfair competition and falsification of organic production, as well as to give them access to various state support mechanisms and to the special market segment - organic produce market, which offers premium prices for the respective produce. The current state of Ukraine's national system of organic market regulation and certification can be characterized as rudimentary. This fact makes it topical to investigate the present gaps, discrepancies and imperfections of the national legislation, which obstruct the effective functioning of organic certification and organic market monitoring systems in Ukraine.

Analysis of recent research and publications. The issues of economic, organizational and legal aspects of organic farming development in Ukraine as well as the best European practices and experience in this field in the context of their possible adaptation in our country were studied by a number of Ukrainian scientists, such as V.I. Artysh, R.M. Bezus, A.V. Bojko, T.O. Chajka, V.A. Chudovska, O.D. Dyvnych, N.M. Feshchenko, Ye.V. Havaza, T.B. Kharchenko, N.Ya. Kutarenko, V.V. Kyporenko, D.H. Leheza, Yu.O. Lupenko, N.P. Novak, A.V. Rashchenko, O.I. Shkuratov, V.P. Yakobchuk, V.M. Vovk, N.V. Zinovchuk and others. Yet the legal aspects of state regulation and certification systems formation in the organic agricultural sector of Ukraine are fragmentarily and insufficiently highlighted by the researchers and therefore they call for further development.

The objective of the article is to investigate the current state of the regulation and certification system of organic production in Ukraine and to draw the main directions of its improvement based on the best international practices and experience.

Statement of the main results of the study. The initiation of organic certification in Ukraine is dating back to 1990s and it was directed mostly towards Ukrainian exports of grain legumes and oil-bearing crops. Therefore the first certifying companies who were engaged in this process in Ukraine represented the respective countries, which imported Ukrainian agricultural production (Germany, Italy, Netherlands, Austria, France and others) [3, p. 56]. Nowadays Ukrainian farmers can get their farms certified by one of the 15 foreign certifying companies. But the process of organic certification can be quite expensive for agricultural producers: 1,52 thousand Euros for a farm with the area of arable land up to 1000 hectares [6]. In 2007 within the framework of the Swiss-Ukrainian project «Organic Agriculture Certification and Market Development» the first Ukrainian

(C) N.A. Tsymbalista, 2017 
organic certification body LLC «Organic Standard» was founded to make organic certification with reasonable pricing accessible to Ukrainian farmers. And in 2009 it has become internationally accredited.

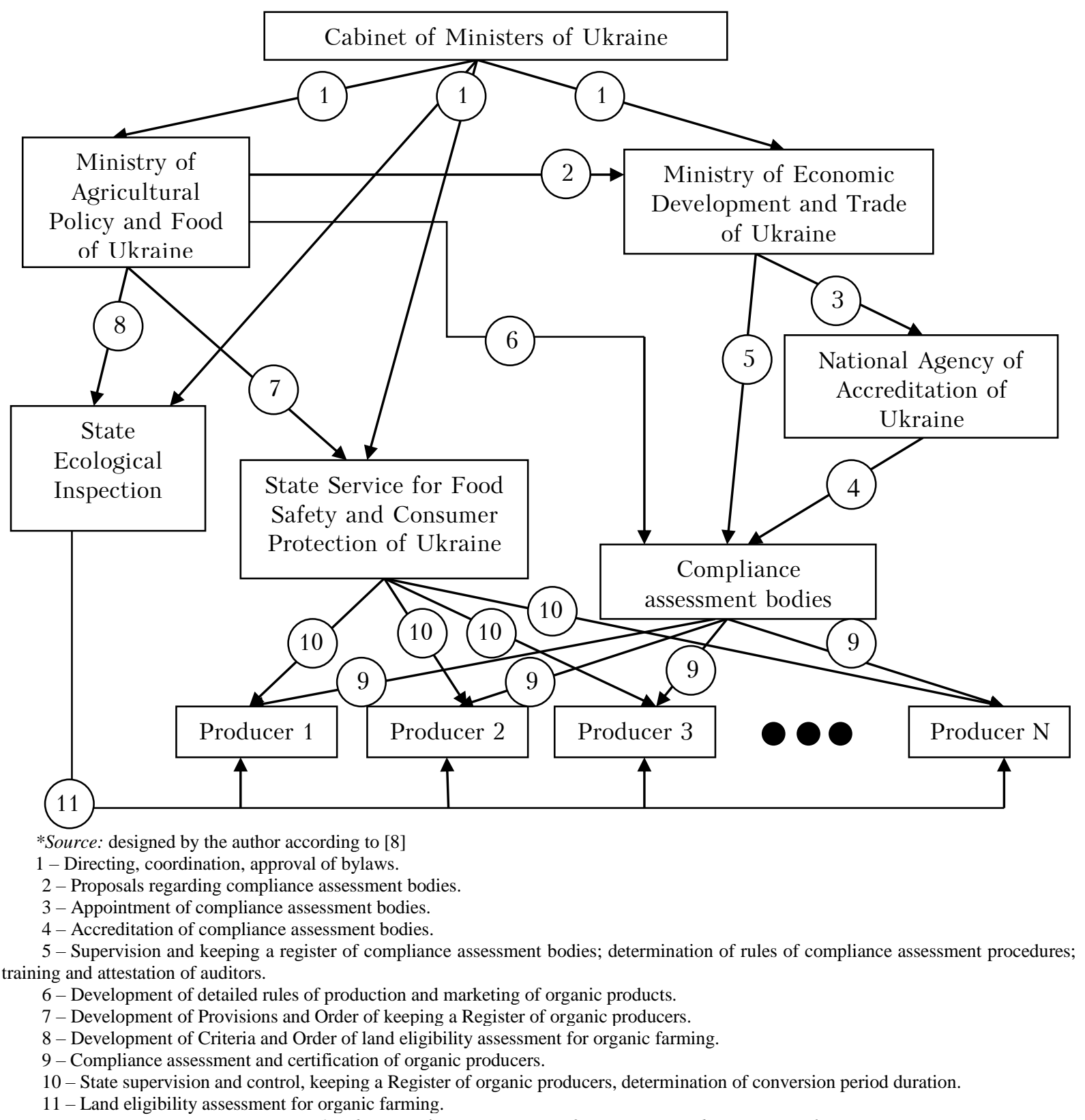

Figure 1. The regulatory system of organic production in Ukraine

During a long period of time (more than 10 years) there were held tough discussions on the issues of development and adoption of the national organic legislation. Finally, at the end of 2013 the Law of Ukraine «On the production and marketing of organic agricultural products and raw materials» was adopted and came into force since January 2014. It establishes the national regulatory system of organic food production and marketing (see fig. 1). Still it is not possible to confirm that the national organic standards and certification system have been created, because the law does not work in a proper manner in fact. Practical implementation of the above mentioned law still requires development and adoption of some bylaws, while the bylaws, which are already approved, need further improvement in order to get in compliance with the European and international requirements.

As shown on the figure, the current regulatory system of organic production in Ukraine is very complicated and entangled. For example, in order to declare the intention to convert to organic farming an agricultural producer should submit an application to the State Service for Food Safety and Consumer Protection of Ukraine which means the beginning of conversion period. At the same time land eligibility for organic farming should be carried out by the State Ecological Inspection (and the time and terms of this procedure are still not fixed). After 
the conversion period is over the producer can apply for organic certification to the Compliance assessment body, which is placed under the Ministry of Economic Development and Trade of Ukraine. Certified producers are to be listed by the State Service for Food Safety and Consumer Protection in the Register of organic producers. According to the Law [8] the State Service for Food Safety and Consumer Protection also carries out state supervision and control over organic producers to ensure that their activities comply with the accepted organic standards, but till now these powers are not mentioned in the Statute of this State Service.

With the described procedure it is not clear on which stage of conversion producers should apply for land eligibility assessment to the State Ecological Inspection and which institution is responsible for monitoring the process of conversion of agricultural producers to organic standards. On the one hand, compliance assessment bodies unlike the State Service for Food Safety and Consumer Protection are supposed to have at their disposal specially trained specialists. But on the other hand, they are engaged into the regulatory system only on the stage of certification. Yet, despite of the fact that compliance assessment bodies do not participate in monitoring they are empowered to nullify certification of a producer in case of identifying any infringements of organic standards, but there is no clear procedure of interaction between the State Service which conducts monitoring and the compliance assessment bodies. In addition, compliance assessment bodies should be accredited by the National Agency of Accreditation, but in fact this Agency does not have specialists of the respective qualification. Another problem is that the current legislation does not require regular recertification. It contradicts with the practice and experience of the European countries, where organic operators are constantly monitored and undergo inspections by organic certification bodies every 1.5 years [9, p. 124].

There are three main types of organic control systems in the European countries: private, state and combined (public-private) systems [1, p. 257-258]. The first model is the most popular and it has two levels: on the first level state authorities accredit private entities to certify organic producers and these certification bodies are monitored by the State; on the second level, accredited certifying bodies carry out certification, annual recertification, monitoring and control over organic operators (producers, food processors and traders). According to the second model all the powers relating to organic certification are concentrated in the state authorities and institutions. The third, combined (public-private), model of control system is designed In the same way as the private one, but it additionally provides a more tough control over organic operators and certification bodies due to planned (announced) and spot (unannounced) inspections of organic producers, processors and traders, which are carried out by the state authorities responsible for organic production and market regulation.

The current Ukrainian regulatory system of organic production is designed based on the last of the above mentioned approaches. Yet, in our opinion, the state supervision over the organic operators is excessive, in particular concerning the land eligibility assessment, which should be performed by the State Ecological inspection. This thesis is based on the fact, that the actual European standards used in Ukraine for the last decades do not require a separate land quality and appropriateness assessment [2, p. 5]. That's why we strongly believe there is no need to complicate the organic certification procedure for Ukrainian farmers. On the other hand, taking into account that the quality characteristics of the final agricultural production depend on the ecological and toxicological indicators of soil contamination, which cannot be addressed as easily as the other components of the production process (such as the quality of agricultural inputs used, soil management approaches, methods to manage pest and disease problems, ways to supply crops' nutritional needs in accordance with the organic requirements), it is important to provide agricultural producers, who are willing to enter the sector of organic agriculture, with appropriate information and consulting support via agricultural advisory services, chambers of agriculture, associations of farmers / organic farmers etc. in a close collaboration with research and scientific institutions (such as State institution «Soil Protection Institute of Ukraine»), state institutions (regional departments of the State technological center of soil fertility protection) and private organizations (for example LLC «Ukrainian center of soil ecology»).

It is also extremely important to strengthen amenability of business entities in case of infringement the laws on organic agriculture and organic products marketing, because nowadays the consumers in fact are not protected from falsification of organic products, as far as the penalties provided by the current legislation are insufficient and not clearly fixed. In addition besides the threats of unfair competition today the genuine organic agricultural producers are in fact brought out of the legal framework of functioning on the domestic market, because according to the Law [8] they are not allowed to label and sell their production on the organic market until they are listed in the State Register, which hasn't been created till the present day.

Conclusions. Some of the above mentioned problems might be solved with the adoption of the new Draft Law «On the basic principles and requirements for organic production, handling and labeling of organic products», which is now pending under the consideration in the Parliament [7]. For example, the new Draft Law clarifies the terms of conversion period beginning, which is to be determined after the first inspection carried out by an accredited certifying (compliance assessment) body. Thus, the functions related to supervision during the conversion period and the final certification will be no longer dispersed between different institutions. Another thing is that the Ministry of Agricultural Policy and Food of Ukraine will become the holder of all the registers, 
related to organic production: the registers of organic operators (producers, processors and traders), organic certifiers and organic seeding materials. In addition the present legal requirement to perform a compulsory land eligibility assessment is going to be cancelled. However despite all the positive moments the new regulation can bring to life a particular institutional gap, which lies in the new requirements to organic certification bodies: they should be legal entities and only residents of Ukraine (this means that all of the 15 foreign certifying companies which have been working with Ukrainian organic producers for the last decades will not comply with the new legislation, while the process of creation of the other Ukrainian certifiers, besides the LLC «Organic Standard», and their international accreditation will probably take some time).

Following the above mentioned we can draw set of conclusions: firstly, it is important to approximate the national certification system to the European organic standards in order to enable access to the international organic produce market for domestic producers; secondly, we need to design an orderly regulation system with a clear subordination and coordination of powers and responsibilities between the state authorities and private entities; thirdly, prior to delegating any powers or responsibilities to any state institution or private legal entity and introduction of any new restrictions or requirements it is important to make sure that the respective institutions have enough qualified and well-trained professionals in place and are ready to comply with the new regulations.

\section{References:}

1. Chudovska, V.A., Shkuratov, O.I. and Kyporenko, V.V. (2016), Ecological and economic mechanism of development of organic agriculture: theory and practice, LLC «DKTs-Center», Kyiv. [In Ukrainian].

2. Fateev, A., Smirnova, Ye., Semenov, D., Luchnikova, Ye. and Shemet, A. (2014), «Assessment of fitness of soils of Ukraine for organic farming under the contents of trace substances», News of agrarian sciences, No. 4 (734), pp. 5-9.

3. Kutarenko, N.Ya. (2012), «Peculiarities of certification of organic production by the agricultural enterprises», Bulletin of Khmelnytsky national university, No. 3, Vol. 1, pp. 55-60. [In Ukrainian].

4. Lupenko, Yu.O. (2013), Formarion of demand and supply on the market of organic products. Organic production and food security, Publishing house «Polissya», Zhytomyr. [In Ukrainian].

5. Organic in Ukraine, available at: http://www.organic.com.ua/en/homepage/2010-01-26-13-42-29 [In Ukrainian]

6. Slyva, Yu. (2016, March), «How to convert to organic farming?», Agribusiness today, available at: http://www.agro-business.com.ua/ideii-i-trendy/5221-iak-pereity-na-organichne-zemlerobstvo.html [In Ukrainian].

7. Supreme Council of Ukraine (2016), On the basic principles and requirements for organic production, handling and labeling of organic products, Draft Law of Ukraine, submitted on 2016, November 24, N 5448ю, available at: http://w1.c1.rada.gov.ua/pls/zweb2/webproc4_1?pf3511=60576 [In Ukrainian].

8. Supreme Council of Ukraine (2013), On the production and marketing of organic agricultural products and raw materials, Law of Ukraine, adopted on 2013, September 3, N 425-VII, available at: http://zakon0.rada.gov.ua/laws/show/425-18 [In Ukrainian].

9. Tymoshenko, V.N., Muzyka, A.A., Zynovenko, A.L., Shejhratsova, L.N. and Shmatko, N.N. (2014), From application to organic-labeling on the example of the EU directives. Organic production and food security, Publishing house «Polissya», Zhytomyr. [In Russian].

TSYMBALISTA Nataliya Andriyivna - PhD in economics, researcher, State Institution «Institute of Regional Research named after M.I. Dolishniy of the National Academy of Sciences of Ukraine».

Scientific interests:

- rural development;

- agricultural cooperation;

- regional economy.

E-mail: cimbal.natalya@gmail.com. 